6. Zhang, H. et al. In situ high resolution of fluxes of $\mathrm{Ni}, \mathrm{Cu}, \mathrm{Fe}$, and $\mathrm{Mn}$ and concentrations of $\mathrm{Zn}$ and Cd in porewaters by DGT. Geochim. Cosmochim. Acta 59, 4181-4192 (1995).

7. Paerl, H. W. \& Pinckney, J. L. A mini-review of microbial consortia: Their roles in aquatic production and biogeochemical cycling. Ecology 31, 225-242 (1996).

8. Xue, H.-B., Stumm, W. \& Sigg, L. The binding of heavy metals to algal surfaces. Wat. Res. 22, 917-926 (1988).

9. Zhang, H. \& Davison, W. Performance characteristics of diffusion gradients in thin films for the in situ measurement of trace metals in aqueous solution. Anal. Chem. 67, 3391-3400 (1995).

10. Davison, W., Zhang, H. \& Grime, G. W. Performance characteristics of gel probe used for measuring pore waters. Environ. Sci. Technol. 28, 1623-1632 (1994).

11. Davison, W., Grime, G. W. \& Woof, C. Characterization of lacustrine iron sulfide particles with proton-induced X-ray emission. Limnol. Oceanogr. 37, 1770-1777 (1992).

12. Davison, W., Grime, G. W., Morgan, J. W. \& Clarke, K. Distribution of dissolved iron in sediment porewaters at submillimetre resolution. Nature 352, 323-325 (1991).

13. DeVitre, R., Belzile, N. \& Tessier, A. Speciation and adsorption of arsenic on diagenetic iron oxyhydroxides. Limnol. Oceanogr. 36, 1480-1485 (1991)

14. Wehrli, B., Friedl, G. \& Manceau, A. in Aquatic Chemistry: Principles and Applications of Interfacial and Interspecies Interactions in Aquatic Systems (eds Huang, P. et al.) 111-134 (Am. Chem. Soc., Washington DC, 1994)

15. Hamilton-Taylor, J. \& Davison, W. in Physics and Chemistry of Lakes 2nd edn, Ch. 8 (eds Lerman, A., Imboden, D. \& Gat, J.) 217-263 (Springer, Berlin, 1995)

16. Bender, J., Rodriguez-Eaton, S., Ekanemesang, U. M. \& Philips, P. Characterization of metal-binding bioflocculants produced by the cyanobacterial component of mixed microbial mats. Appl. Environ Micrbiol. 60, 2311-2315 (1994).

17. Brendel, P. J. \& Luther, G. W. Development of a gold amalgam voltammetric microelectrode for the determination of dissolved $\mathrm{Fe}, \mathrm{Mn}, \mathrm{O}_{2} \& \mathrm{~S}(-\mathrm{II})$ in porewaters of marine and freshwater sediments. Environ. Sci. Technol. 29, 751-761 (1995).

Acknowledgements. We thank H. Zhang for comments and A. Hunt for algal identification. This work was supported by the NERC.

Correspondence and requests for materials should be addressed to W.D. (e-mail: w.davison@lancaster ac.uk).

\section{Measuring the pulse of a plume with the sedimentary record}

\section{Nicky White ${ }^{\star}$ \& Bryan Lovell $\dagger \ddagger$}

* Bullard Laboratories, Madingley Rise, Madingley Road, Cambridge CB3 OEZ, $U K$

$\dagger$ BP Exploration, Britannic House, 1 Finsbury Circus, London EC2M 7BA, UK

Magmatic underplating associated with mantle plume activity is an important mechanism for driving regional surface uplift and denudation of large portions of the continents ${ }^{1,2}$. Such uplift occurs rapidly because substantial volumes of basaltic melt are added to the crust over geologically short periods of time (1$10 \mathrm{Myr})^{2}$, and can lead to large amounts of clastic sediment being shed into surrounding basins ${ }^{3}$. An intensively studied example of this process occurred in the North Sea basin during the Palaeogene period, where discrete pulses of deposition were triggered when sands were remobilized downslope from the shelf by turbidity currents and debris flows as a result of episodic changes of relative sea level ${ }^{3}$. Here we correlate the timing of these sediment pulses with the timing of surface uplift inferred to have been caused by episodic magmatic underplating on the continental shelf of northwestern Europe. This magmatism was related to activity of the Iceland plume, suggesting that individual pulses of sedimentation provide a potentially sensitive measure of plume activity, and so may be used to resolve time-dependent fluctuations in mantle plume activity predicted by theoretical studies of mantle convection.

We have chosen to examine the northwest shelf of Europe for three reasons. First, the history of vertical motions has been carefully studied ${ }^{3}$ over the past 20 years. Second, the distribution, composition, volume and age of onshore and offshore igneous activity are well documented ${ }^{4-7}$. Third, the biostratigraphy, chronostratigraphy and seismic stratigraphy of Palaeogene sedimentary rocks have been systematically studied using both onshore data and extensive seismic and well data made available by the hydrocarbon industry $y^{3,8}$.

† Present address: Bullard Laboratories, Madingley Rise, Madingley Road, Cambridge CB3 0EZ, UK.
In the Early Cenozoic era, an area encompassing the British Isles $\left(\sim 3 \times 10^{5} \mathrm{~km}^{2}\right)$ underwent rapid exhumation (Fig. 1). Substantial quantities of Palaeogene muds and sands were deposited in the North Sea and in other basins including the Faeroe-Shetland basin, the Porcupine basin west of Ireland and southeastern England ${ }^{9-11}$. Marine sedimentation was strongly pulsed, suggesting a pattern of transgression and regression which was first recognized by Lavoisier in 1766. A detailed history of highstands and lowstands of Palaeogene relative sea level in the North Sea basin is now available ${ }^{12,13}$. These relative sea-level changes are recognizable around the British Isles but their magnitude and timing cannot be correlated throughout northwestern Europe or worldwide ${ }^{13}$. This observation indicates that global (that is, eustatic) sea-level variation did not control the cyclic pattern of deposition. We are especially concerned with the period between 62 and 54 Myr ago when a series of submarine fans formed at intervals of $\sim 1$ Myr on either side of the emergent Scottish landmass. These pulses of sand deposition are well documented in the North Sea and coeval pulses have been recognized in the Faeroe-Shetland basin ${ }^{14}$.

Permanent uplift and denudation of a region encompassing the British Isles were triggered by Palaeogene magmatic underplating ${ }^{1,15}$. Geochemical and subsidence modelling show that this magma was generated by adiabatic decompression of asthenosphere with a potential temperature of $1,450-1,500{ }^{\circ} \mathrm{C}$, requiring the existence of a mantle plume ${ }^{4,16}$. The existence of a possible 50-250 $\mathrm{m}$ of transient dynamic uplift associated with the proto-Iceland plume ${ }^{2,17}$ cannot account for permanent uplift and does not affect our principal conclusions. Assuming Airy isostasy, the amount of magmatic underplating, $X$, required to generate an amount of denudation, $D$, is given by

$$
X=\left(\frac{\rho_{\mathrm{a}}-\rho_{\mathrm{s}}}{\rho_{\mathrm{a}}-\rho_{X}}\right) D+\left(\frac{\rho_{\mathrm{a}}}{\rho_{\mathrm{a}}-\rho_{X}}\right) T+\left(\frac{\rho_{\mathrm{a}}-\rho_{\mathrm{w}}}{\rho_{\mathrm{a}}-\rho_{X}}\right) W
$$

where $T$ is the present-day topography (that is, residual uplift) and $W$ is the water depth during the Late Cretaceous before uplift. Other parameters are given in Table 1 . In the Irish Sea, $\sim 2.5 \mathrm{~km}$ of strata have been eroded from extant Permian-Triassic basins and there is little residual uplift. If Late Cretaceous water depths were in the range $200-600 \mathrm{~m}$, the required underplate is $8 \pm 2 \mathrm{~km}$. If the same amount of underplating occurred beneath Scotland where Late Cretaceous water depths were $0-300 \mathrm{~m}$, an average present-day topography of $\sim 500 \mathrm{~m}$ implies that $D$ is $0.5-2 \mathrm{~km}$. This estimate of $D$ is consistent with fission track analyses ${ }^{18}$ and with emplacement depths for igneous complexes ${ }^{4}$. If $\rho_{X}$ is reduced to $2.8 \mathrm{Mg} \mathrm{m}^{-1}$, then $X=6 \pm 1 \mathrm{~km}$.

Widespread magmatism is manifested at the surface by numerous central igneous complexes, lavas, linear dyke swarms, and other, minor, intrusive bodies (Fig. 1). Although accurate volumetric estimates of magmatism are difficult to make, studies of petrological fractionation support the notion that a substantial volume of magmatic underplating exists (3-5 times the volume inferred from outcrop $\left.{ }^{1}\right)$. Large volumes are corroborated by forward and inverse modelling of concentrations of rare-earth elements for basaltic rocks. After corrections for fractional crystallization of the observed melt compositions, these data indicate that $\sim 5 \mathrm{~km}$ of melt was produced at depth ${ }^{4}$. Wide-angle and deep seismic reflection data provide a further important constraint for the amount of underplating ${ }^{2}$. The lower crust beneath the British Isles is strongly reflective and has a Poisson's ratio of $\sim 1.86$, consistent with the existence of mafic sills. Beneath Scotland, the Lithosphere Seismic Profile in Britain (LISPB) wide-angle data set shows that P-wave velocity increases sharply at $20 \mathrm{~km}$ depth, and that the velocity 5$8 \mathrm{~km}$ above the Moho is $6.6-7 \mathrm{~km} \mathrm{~s}^{-1}$ with calculated densities of 2.85-3.05 $\mathrm{Mg} \mathrm{m}^{-3}$ (ref. 19). Thus geochemical and geophysical observations are consistent with the underplating hypothesis.

Dating of onshore igneous rocks has proved difficult because of significant argon mobility and most of the published $\mathrm{K}-\mathrm{Ar}$ ages are 
uncertain. Reliable ${ }^{40} \mathrm{Ar} /{ }^{39} \mathrm{Ar}$ step-heating and $\mathrm{Rb}-\mathrm{Sr}$ isochron ages $^{5-7}$ have an analytical precision of $0.5-1.5 \mathrm{Myr}$ but magnetic polarity data measurements can be used further to constrain the ages $^{20}$. Combined age and polarity data for all of the igneous centres show that magmatism lasted from 62 to $52 \mathrm{Myr}$ ago, with a peak between 61 and 58 Myr.

The main pulses of submarine-fan sedimentation correlate with periods of most intense magmatic activity (Fig. 2). The phase of greatest fan development (Andrew) coincides with the acme of

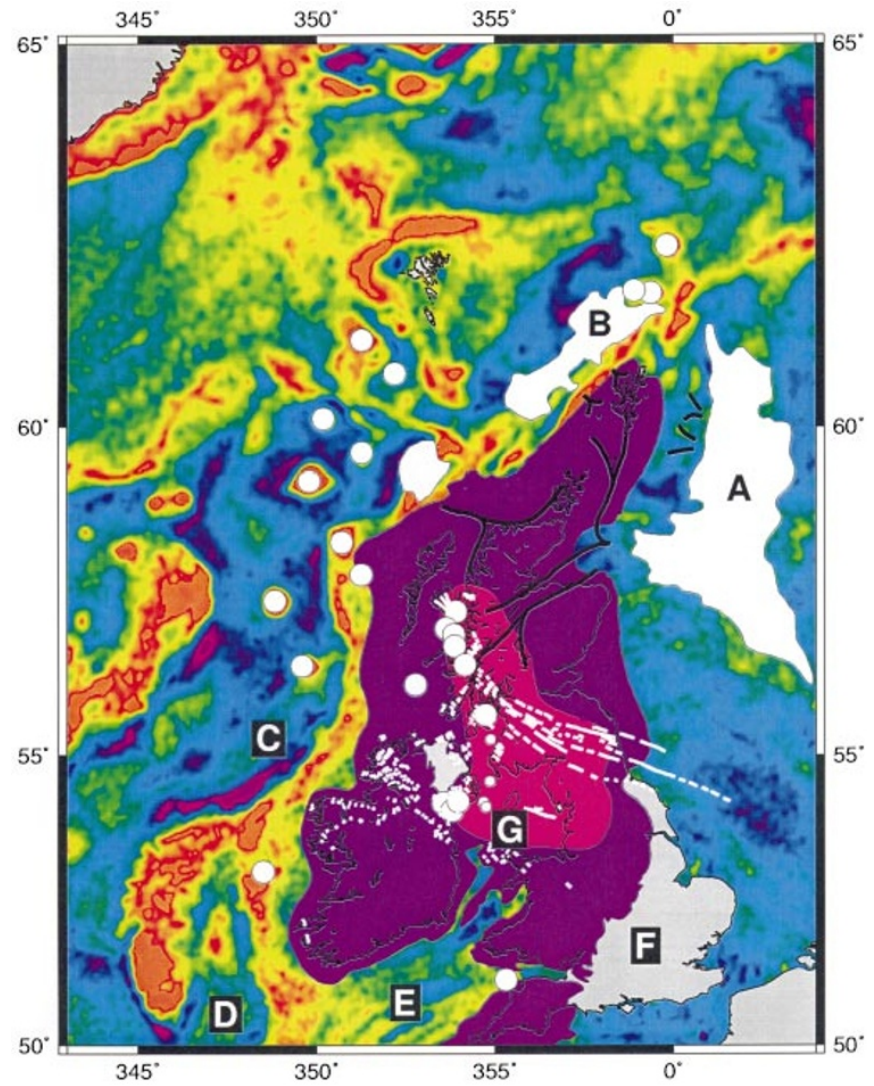

Figure 1 Satellite free-air gravity map of the British Isles (see Fig. 3 legend). The purple area encompassing the British Isles shows the region that underwent 0.5$1 \mathrm{~km}$ of denudation during the Palaeogene $\left(\sim 3 \times 10^{5} \mathrm{~km}^{2}\right)$; the pink area shown underwent $2-3 \mathrm{~km}$ of denudation; the light grey patches offshore indicate submarine fan deposition in the North Sea and in the Faeroe-Shetland basin at time of maximum input (59 Myr ago: labelled 'Andrew' in Fig. 2); large white circles, major intrusive centres; small white circles and lines, minor intrusive centres, dykes and sills. A, North Sea; B, Faeroe-Shetland basin; C, Slyne-Erris basin; D, Porcupine basin; E, Celtic Sea basin; F, London-Hampshire basin; G, Irish Sea. Thick black lines indicate drainage pattern inferred from location of major channels offshore, from provenance studies, and from geomorphology. The denudation pattern is constrained by modelling subsidence analyses, vitrinite reflectance profiles, fission track data and sonic velocity information (refs 15,18 , and E. Rowley and K. Gallagher, personal communication). These data show that $1-3 \mathrm{~km}$ of denudation occurred rapidly during a period when climate was warm and relatively stable compared with the succeeding Neogene ${ }^{8}$. Increasing amounts of denudation have occurred in a transect from the Hampshire basin towards the Irish Sea where $2-3 \mathrm{~km}$ of strata have been removed. A maximum of $\sim 1 \mathrm{~km}$ has been removed from most of Scotland. The submarine fan system shown in the North Sea consists of a large $\left(\sim 60,000 \mathrm{~km}^{2}\right)$ wedge of sand up to $700 \mathrm{~m}$ thick. Coeval fan systems in the northern North Sea and in the FaeroeShetland basin are smaller. Correlatable mineralogical units can be identified within Palaeogene submarine fan sequences. Systematic changes in sediment provenance reflect variations in source area composition, from Mesozoic and Palaeozoic sandstones to Moine and Dalradian metamorphic basement ${ }^{26}$. magmatism between 61 and $58 \mathrm{Myr}$, within chron C26r. We infer that each phase of magmatism caused rapid uplift. Fan volumes and denudation estimates imply average erosion rates of $200 \pm 100 \mathrm{~mm} \mathrm{kyr}^{-1}$ during the period of interest, compatible with the range of global geomorphic estimates for fluvial systems ${ }^{21}$. More importantly, phased uplift gave rise to episodic lowstands of relative sea level. Each lowstand triggered the transport of sediment already on the shelf, downslope into deeper waters. The development of submarine fans in such a setting is particularly sensitive to changes

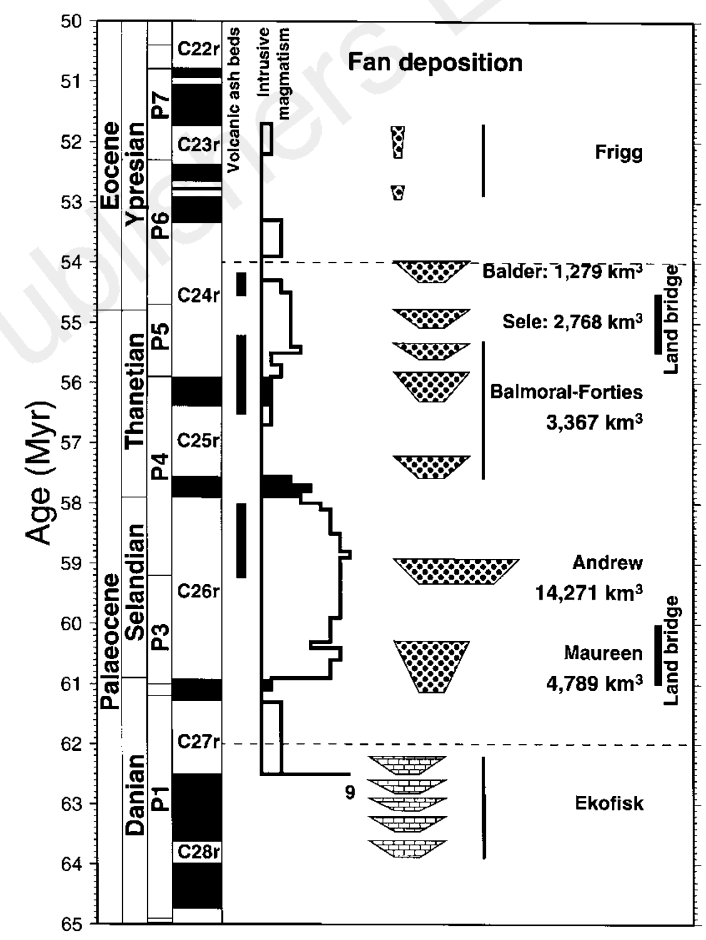

Figure 2 Stratigraphic chart based on timescale of Berggren et al. ${ }^{20}$ and showing temporal relationship between intrusive igneous activity ${ }^{5-7}$, offshore volcanic ash beds ${ }^{8,11}$, and submarine fan deposition in North Sea ${ }^{13}$. At the left-hand side, stage names, planktonic foraminiferal biostratigraphic zonation and magnetostratigraphy are shown. The histogram of igneous activity (total of 35 ages) includes the total error estimate of age (monitor mineral is the Bern biotite 4B: $17.19 \pm 0.12 \mathrm{Myr}$ ). Magnetic polarity was used to position dates within the appropriate chron (black, normal polarity). Wedges with filled circles indicate aggregated submarine fan deposits. The nomenclature follows $\mathrm{Neal}^{13}$ and volume estimates are based on Reynolds ${ }^{27}$. Horizontal dashed lines at 62 and $54 \mathrm{Myr}$ mark initiation of the Iceland plume and the start of sea-floor spreading between Greenland and Europe, respectively. Note land bridges at start and end of 8-Myr period of interest (see Hooker in ref. 8). Danian rocks include submarine fans (wedges with brick shading which are labelled 'Ekofisk') which consist of reworked chalk derived from the erosion of Cretaceous strata that covered most of the British Isles ${ }^{3,11}$. The first major influx of clastic sediments (Maureen) occurred between 61.1 and 60.3 Myr ago. This fan system comprises 20\% of the total volume of submarine fan deposits in the Palaeogene. The succeeding Andrew fan system (59.4-58.9 Myr) represents $\sim 50 \%$ of the total volume of submarine fan sediment with an implied minimum discharge of $1 \mathrm{~m}^{3} \mathrm{~s}^{-1}$, equivalent to $7 \times 10^{10} \mathrm{~kg} \mathrm{yr}^{-1}$. Between 58 and $54 \mathrm{Myr}$, the Balmoral-Forties, Sele and Balder fan systems were generated with a combined volume of $\sim 20 \%$. Total fan volume in the North Sea from 62 to $54 \mathrm{Myr}$ is $\sim 26,000 \mathrm{~km}^{3}$ $\left(\sim 6 \times 10^{16} \mathrm{~kg}\right)^{27}$. By Early Ypresian times $(54 \mathrm{Myr})$, submarine fan volumes were considerably smaller. 


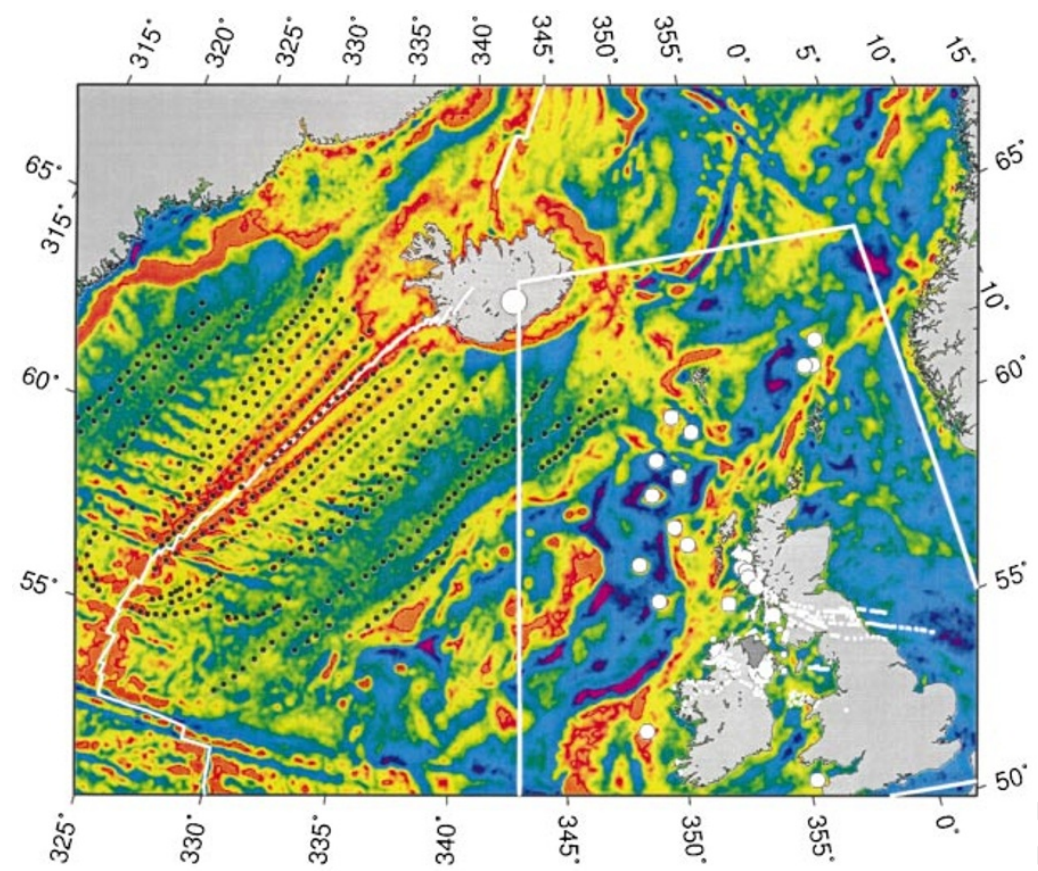

Figure 3 Satellite-derived free-air gravity map of Sandwell and $\mathrm{Smith}^{28}$ for the North Atlantic Ocean (equal area projection). Red/yellow colours indicate gravity highs and purple/blue colours indicate gravity lows. The large white circle on Iceland indicates the location of the present-day plume centre at Vatnajökull $\left(64.5^{\circ} \mathrm{N}, 17.3^{\circ} \mathrm{W}\right)$. Up to $500 \mathrm{~km}$ southwest along the Reykjanes ridge spreading centre, indicated by the solid white line, asthenospheric potential temperatures of $\sim 1,450^{\circ} \mathrm{C}$ result in the generation of a $14-\mathrm{km}$-thick oceanic crust ${ }^{2}$. Filled circles delineate prominent $\mathrm{V}$-shaped ridges which transgress the magnetic anomaly pattern ${ }^{22,23}$. These ridges are symmetrical about the spreading axis and converge southwards thus crossing progressively younger crustal isochrons. A less obvious set of $\mathrm{V}$-shaped ridges occur north of Iceland. Isostatic calculations, wide-angle seismic data and rare-earth element modelling show that the crust is thicker beneath the most prominent ridges ${ }^{23,24}$. V-shaped ridges are generated when pulses of anomalously hot asthenosphere flow down the spreading axis. The variation in crustal thickness indicates that asthenospheric potential temperatures beneath the plume fluctuate by $\pm 30^{\circ} \mathrm{C}$ (ref. 24). Radial flow velocities required to produce $V$-shaped ridges can be calculated from Fig. 4. Features shown within white box are identified in Fig. 1.

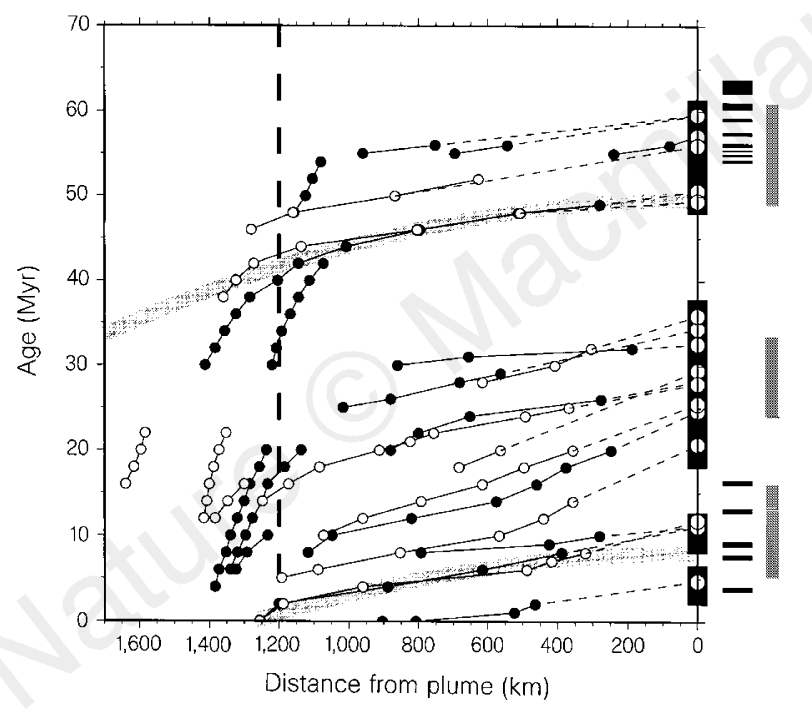

Figure $4 \mathrm{Age}$ of $\mathrm{V}$-shaped ridges plotted as a function of distance from the plume centre (updated from Vogt ${ }^{22}$ ). At any given distance, the age of a ridge is determined from its intersection with the sea-floor spreading isochrons (for example, Müller et al. ${ }^{29}$ ) which were calculated by linear interpolation between magnetic anomaly picks. Solid circles, ridges southeast of mid-ocean ridge; open circles, ridges northwest of mid-ocean ridge. Note approximate symmetry of ridges about spreading axis. Slope gives velocity of any high-temperature pulse as it travels down the spreading axis from northeast to southwest. These pulses travel $\sim 800 \mathrm{~km}$ at an average velocity of $\sim 10 \mathrm{~cm} \mathrm{yr}^{-1}$, with a rapid decrease to $\sim 1 \mathrm{~cm} \mathrm{yr}^{-1}$ at $\sim 1,200 \mathrm{~km}$ from the plume centre. Dashed lines and open circles extrapolate back to plume centre using a velocity which is averaged over last 3 points. Solid vertical bars at $0 \mathrm{~km}$ give range of starting times if velocity varies from 0 to $20 \mathrm{~cm} \mathrm{yr}^{-1}$. Solid horizontal bars (55-65 Myr), sediment pulses shown on Fig. 2; solid horizontal bars (0-20 Myr), radial plume pulsation from Wright and Millers ${ }^{31}$ seismic reflection and palaeoceanographic data analysis. Grey vertical bars, periods of minor upper-crustal shortening observed at continental margin north of Scotland ${ }^{30}$; thick grey curves, calculated velocity of asthenospheric pulse assuming that plume flux is radial, varying according to equation (2) using parameters given in Table 1. At least six pulses have occurred during the past $30 \mathrm{Myr}$. V-shaped ridges appear to be absent between 35 and $50 \mathrm{Myr}$ ago, indicating an hiatus in plume temperature fluctuation. Older diachronous ridges (40-60 Myr) are evident closer to the continental margins on either side of the ocean basin. Their velocities agree with those calculated for more prominent, younger, ridges. We suggest that at least three pulses originated at the plume centre between 60 and 50 Myr ago, taking 1 Myr to travel for the plume centre to the British Isles, $500 \mathrm{~km}$ away.

in relative sea level ${ }^{8,9,12}$. This well established sensitivity allows us to highlight the significance of a correlation between episodes of submarine fan deposition and uplift events probably caused by igneous activity. Modern and Quaternary studies demonstrate that the time lag between onset of a lowstand event and triggering of deposition is negligible for our purposes $\left(<10^{5} \mathrm{yr}\right)$. The Palaeogene sedimentary record is proposed here as a measure of pulsed magmatic underplating, and can be regarded as a proxy for plume activity between 62 and $54 \mathrm{Myr}$ ago. Once sea-floor spreading between Greenland and Europe began 54 Myr ago, the continental margin moved away from the plume centre and submarine fan volumes in the North Sea decreased markedly ${ }^{3,9}$.

The extent and magnitude of denudation suggest that the average

rate of melt addition beneath the entire British Isles was $0.1 \mathrm{~km}^{3} \mathrm{yr}^{-1}$. If the proportional change of submarine fan volume through time was triggered by surface uplift, which in turn was caused by variation in magmatic underplating, then the rate of melt addition fluctuated between 0.05 and $0.14 \mathrm{~km}^{3} \mathrm{yr}^{-1}$. This fluctuation could be produced by variation in asthenospheric potential temperature of $\pm 30^{\circ} \mathrm{C}$. Our inference can be tested using independent but less well resolved evidence for fluctuations in plume activity over the past $60 \mathrm{Myr}$. $\operatorname{Vogt}^{22,23}$ first showed that prominent V-shaped ridges occur on the sea floor, south of Iceland (Fig. 3). Later work suggested that these ridges result from pulses of hotter asthenosphere travelling away from the centre of the plume ${ }^{24}$. We determined the velocity and starting age of hot pulses of asthenosphere required to produce 


\begin{tabular}{|c|c|c|}
\hline Symbol & Definition & Value \\
\hline$\rho_{\mathrm{a}}$ & Density of asthenosphere & $3.2 \mathrm{Mg} \mathrm{m}^{-3}$ \\
\hline$\rho_{\mathrm{S}}$ & Density of sedimentary rock & $2.6 \mathrm{Mg} \mathrm{m}^{-3}$ \\
\hline$\rho_{\mathrm{W}}$ & Density of water & $1 \mathrm{Mg} \mathrm{m}^{-3}$ \\
\hline$\rho_{X}$ & Density of magmatic underplating & $2.9 \mathrm{Mg} \mathrm{m}^{-3}$ \\
\hline$\ddot{M}$ & Mass flux of plume & $2 \times 10^{14} \mathrm{kgyr}^{-}$ \\
\hline$h$ & Thickness of plume & $100 \mathrm{~km}$ \\
\hline$R$ & Radius of plume & $1,000 \mathrm{~km}$ \\
\hline
\end{tabular}

these ridges (Fig. 4). Downstream deceleration of each pulse is in accordance with the variation of residual depth and crustal thickness away from the plume centre ${ }^{24}$.

For pulses travelling radially outwards from the plume centre, the distance of a pulse from the centre of the plume, $R$, at any time, $t$, is given by

$$
R=\sqrt{\frac{\dot{M} t}{\pi h \rho_{\mathrm{a}}}}
$$

Using the parameter values given in Table 1 , the geometry of the $\mathrm{V}$ shaped ridges is consistent with rapid radial asthenospheric flow out to $1,200 \mathrm{~km}$; there is not a requirement for pulses to be channelled exclusively along the Reykjanes ridge ${ }^{25}$. This assertion is consistent with the geochemistry of ridge axis basalts if the radial flow beneath the ridge axis did not pass through the melting column beneath Iceland and if the plume centre is not located exactly on the ridge axis. Temperature variation within the core of the plume will also cause fluctuations in the pressure head at a mid-ocean ridge. Consequent changes in maximum compressive stress at the surrounding continental margins coincided with three discrete phases of mild folding and thrust faulting which occurred when pulsing of the plume was important (Fig. 4). However, these very modest amounts of crustal shortening cannot be responsible for Palaeogene uplift and denudation of the British Isles.

Several different data sets support our hypothesis that the existence of discrete pulses of Palaeogene submarine fan deposition is linked to mantle plume activity. Sedimentary deposits may therefore help to resolve otherwise inaccessible details of mantle plume activity on timescales of $0.5-1$ Myr. We suggest that a global analysis of sedimentological data from hotspot settings would be fruitful.

Received 5 December 1996; accepted 13 May 1997

1. Cox, K. G. Continental magmatic underplating. Phil. Trans. R. Soc. Lond. A 342, 155-166 (1993).

2. White, R. S. \& McKenzie, D. Magmatism at rift zones: The generation of volcanic continental margins and flood basalts. J. Geophys. Res. 94, 7685-7729 (1989).

Parker, J. R (ed.) Petroleum Geology of Northwest Europe (Geol. Soc., London, 1993).

4. Brodie, J. A. Early Tertiary magmatism in the North Atlantic. Thesis, Univ. Cambridge (1995).

5. Mussett, A. E., Dagley, P. \& Skelhorn, R. R. Time and Duration of Activity in the British Tertiary Igneous Province 337-348 (Spec. Publ. 39, Geol. Soc., London, 1988).

6. Mussett, A. E. \& McCormack, A. G. Magnetic Polarity Timescales: a New Test 27-37 (Spec. Publ. 70, Geol. Soc., London, 1992).

7. Pearson, D. G., Emeleus, C. H. \& Kelly, S. P. Precise ${ }^{40} \mathrm{Ar} /{ }^{39} \mathrm{Ar}$ age for the initiation of Palaeogene volcanism in the Inner Hebrides and its regional significance. J. Geol. Soc. Lond. 153, 815-818 (1996).

8. Knox, R. W. O’B., Corfield, R. M. \& Dunay, R. E. Correlation of the Early Paleogene in Northwest Europe (Spec. Publ. 101, Geol. Soc., London, 1996).

9. Milton, N. J., Bertram, G. T. \& Vann, I. R. Early Palaeogene Tectonics and Sedimentation in the Central North Sea 339-351 (Spec. Publ. 55, Geol. Soc., London, 1990).

10. Shannon, P. M. Early Tertiary Submarine Fan Deposits in the Porcupine Basin, Offshore Ireland 351-373 (Spec. Publ. 62, Geol. Soc., London, 1992).

11. Knox, R. W. O'B. Tectonic Controls on Sequence Development in the Palaeocene and Earliest Eocene of Southeast England: Implications for North Sea Stratigraphy 209-230 (Spec. Publ. 103, Geol. Soc., London, 1996).

12. Stewart, I. J. in Petroleum Geology of North West Europe (eds Brookes, J. \& Glennie, K.) (Graham \& Trotman, London, 1987)

13. Neal, J. E. in Correlation of the Early Paleogene in Northwest Europe (eds Knox, R. W. O.'B., Corfield, R. M. \& Dunay, R. E.) 15-42 (Spec. Publ. 101, Geol. Soc., London, 1996).

14. Mitchell, S. M. et al. in Petroleum Geology of Northwest Europe: Proc. 4th Conf. (ed. Parker, J. R.) 1025 1034 (Geol. Soc., London, 1993).

15. Brodie, J. \& White, N. Sedimentary basin inversion caused by igneous underplating: Northwest European continental shelf. Geology 22, 147-150 (1994)

16. Scarrow, J. H. \& Cox, K. G. Basalts generated by decompressive adiabatic melting of a mantle plume: a case study from the Isle of Skye, NW Scotland. J. Petrol. 366, 3-22 (1995).
17. Nadin, P. A., Kusznir, N. J. \& Toth, J. Transient regional uplift in the early Tertiary of the northern North Sea and the development of the Iceland Plume. J. Geol. Soc. Lond. 152, 953-958 (1995).

18. Green, P. F., Duddy, I. R., Bray, R. J. \& Lewis, C. L. E. in Petroleum Geology of Northwest Europe: Proc. 4th Conf. (ed. Parker, J. R.) 1067-1074 (Geol. Soc., London, 1993).

19. Barton, P. J. LISPB revisited: a new look under the Caledonides of northern Britain. Geophys. J. Int. 110, 371-391 (1992)

20. Berggren, W. A., Kent, D. V., Aubry, M.-P. \& Hardenbol, J. Geochronology, Time Scales and Stratigraphic Correlation: Framework for an Historical Geology. (Spec. Publ. 54, Soc. Econ. Geol. Palaeontol., Tulsa, 1995).

21. Summerfield, M. A. \& Hulton, N. J. Natural controls of fluvial denudation rates in major world drainage basins. J. Geophys. Res. 99, 13871-13883 (1994).

22. Vogt, P. R. Asthenosphere motion recorded by the ocean floor south of Iceland. Earth Planet. Sci. Lett. 13, 153-160 (1971)

23. Vogt, P. R. in Structure and Development of the Geeenland-Scotland Ridge (eds Bott, M. H. P., Saxov, S., Talwani, M. \& Thiede, J.) 191-213 (Plenum, 1983).

24. White, R. S., Bown, J. W. \& Smallwood, J. R. The temperature of the Iceland plume and origin of outward-propagating V-shaped ridges. J. Geol. Soc. Lond. 152, 1039-1045 (1995).

25. Ito, G., Lin, J. \& Gable, C. W. Dynamics of mantle flow and melting at a ridge-centred hotspot: Iceland and the Mid-Atlantic Ridge. Earth Planet. Sci. Lett. 144, 53-74 (1996).

26. Morton, A. C., Hallsworth, C. R. \& Wilkinson, G. C. in Petroleum Geology of Northwest Europe: Proc. 4th Conf. (ed. Parker, J. R.) 73-84 (Geol. Soc., London, 1993).

27. Reynolds, T. Quantitative analysis of submarine fans in the Tertiary of the North Sea Basin. Mar. Petrol. Geol. 11, 202-207 (1994).

28. Sandwell, D. T. \& Smith, W. H. F. Global marine gravity from ERS-1, Geosat and Seasat reveals new tectonic fabric. Eos 73, 133 (1992)

29. Müller, R. D., Roest, W. R., Royer, J.-Y., Gahagan, L. M. \& Sclater, J. G. A Digital Age Map of the Ocean Floor. (Ref. Ser. 93-30, Scripps Inst. Oceanogr., La Jolla, 1993).

30. Doré, A. G. \& Lundin, E. R. Cenozoic compressional structures on the NE Atlantic margin: nature, origin and potential significance for hydrocarbon exploration. Petrol. Geosci. 2, 299-311 (1996).

31. Wright, J. D. \& Miller, K. G. Control of North Atlantic Deep Water circulation by the GreenlandScotland ridge. Paleoceanography 11, 157-170 (1996).

Acknowledgements. We thank D. Aslanian, S. Bergman, J. Brodie, R. England, R. Knox, D. Lyness, S. Lewis, D. McKenzie, F. Nimmo, R. Rickaby and former colleagues of B.L. in BP Exploration, for their help. We also thank K. Cox and K. Gallagher for reviews. Figures were made using Generic Mapping Tools of P. Wessel and W. Smith. This work forms part of the PULSE (Paleogene Uplift Linked to Sediment Efflux) project funded by The British Petroleum Company plc and the Natural Environment Research Council.

Correspondence should be addressed to N.W. (e-mail: nwhite@esc.cam.ac.uk).

\section{A new route for synthesis of dimethylsulphoniopropionate in marine algae}

\section{Douglas A. Gage*, David Rhodes $\dagger$, Kurt D. Nolte $\ddagger$, Wayne A. Hicks ${ }^{\star}$, Thomas Leustek $₫$, Arthur J. L. Cooper\| \& Andrew D. Hanson $\neq$}

* Department of Biochemistry, Michigan State University, East Lansing,

Michigan 48824, USA

$\dagger$ Horticulture Department, Purdue University, West Lafayette, Indiana 47907, USA

$\ddagger$ Horticultural Sciences Department, University of Florida, Gainesville,

Florida 32611, USA

$\$$ Center for Agricultural Molecular Biology, Rutgers University, New Brunswick, New Jersey 08903, USA

II Department of Biochemistry, Cornell University Medical College, New York, New York 10021, USA

The 3-dimethylsulphoniopropionate (DMSP) produced by marine algae is the main biogenic precursor of atmospheric dimethylsulphide (DMS) ${ }^{1-3}$. This biogenic DMS, formed by bacterial and algal degradation of $\mathrm{DMSP}^{4,5}$, contributes about $1.5 \times 10^{13} \mathrm{~g}$ of sulphur to the atmosphere annually ${ }^{3}$, and plays a major part in the global sulphur cycle, in cloud formation and potentially in climate regulation ${ }^{1,3}$. Although DMSP biosynthesis has been partially elucidated in a higher plant ${ }^{6,7}$, nothing is known about how algae make DMSP except that the whole molecule is derived from methionine ${ }^{8-12}$. Here we use in vivo isotope labelling to demonstrate that DMSP synthesis in the green macroalga Enteromorpha intestinalis proceeds by a route entirely distinct from that in higher plants. From methionine, the steps are transamination, reduction and $S$-methylation to give the novel sulphonium compound 4-dimethylsulphonio-2-hydroxybutyrate (DMSHB), which is oxidatively decarboxylated to DMSP. The key 